\title{
POLSKI XVI-WIECZNY PRZEKKAD PORADNIKA PIOTRA KRESCENCJUSZA JAKO ŚWIADECTWO PRZENIKANIA KULTUR
}

DOI: http://dx.doi.org/10.12775/RP.2017.009

\begin{abstract}
Zarys treści: Przedmiotem niniejszego tekstu są występujące w polskim wydaniu poradnika (1571), wyodrębnione graficznie, podane w nawiasach, wyjaśniające uwagi autora. Celem jest ich charakterystyka, odniesienie do łacińskiego pierwowzoru tekstu oraz prześledzenie, jak za ich pomocą starano się adaptować obce realia i zapoznawać z nimi odbiorcę. Poczyniono też porządkującą próbę wyszczególnienia ich rodzajów i funkcji. Omówiony materiał pełni głównie funkcję informacyjną, zarazem objaśnia i tłumaczy tekst, czasem przybliża kontekst kulturowy, jest rodzajem językowego i tematycznego leksykonu, który zapoznaje czytelnika ze zwyczajami i kulturą innych narodów.
\end{abstract}

Słowa kluczowe: XVI-wieczny polski przekład poradnika Krescencjusza, językowe wykładniki przenikania kultur, tekst specjalistyczny, historia języka polskiego

\section{Uwagi wstępne - 0 autorze, dziele i jego przekładach}

Drzedmiotem szkicu uczyniono - graficznie wyróżnione - wtrącenia zamieszczone $\mathrm{w}$ polskim tłumaczeniu znanego średniowiecznego dzieła Piotra Krescencjusza ${ }^{1}$. Tekst „Opus ruralium commodorum libri XII”, napisany po łacinie przed rokiem 1300, po raz pierwszy wydany został, po śmierci

${ }^{1}$ Niniejszy szkic mieści się w nurcie przekładoznawstwa tylko ze względu na wzięty na warsztat przedmiot analizy - polski przekład średniowiecznego poradnika. Badany materiał podlega jednak przede wszystkim oglądowi filologicznemu, a wykorzystane metody należą do zestawu metod lingwistycznych i historycznoporównawczych. 
autora, w Augsburgu w 2. połowie wieku XV (1471). Pietro de Crescenzi, znany też jako Krescentyn (1230-1320 lub 21), a w spolszczonej wersji Krescencjusz, był włoskim agronomem, lekarzem, prawnikiem, przyrodnikiem i senatorem (Wydra, Rzepka 2004: 373-4, NEP 1995: 794). Wszechstronną wiedzę teoretyczną i praktyczną wykorzystał w opisie zasad gospodarowania, które zawarł w dwunastu obszernych księgach swego dzieła. Wykorzystując wiedzę i dorobek minionych stuleci, doświadczenia pisarzy starożytnych i swoje własne zawarł w poradniku, przeznaczonym głównie dla osób zarządzających gospodarstwem, wiele cennych wskazówek i informacji na temat uprawy roślin i hodowli zwierząt. Wyodrębnione, dokładne opisy ziół i ich charakterystyka sprawiły, że tekst ten łączy w sobie cechy poradnika gospodarczego i zielnika. Dzięki zawartym w nim treściom zabytek reprezentujący literaturę użytkową wpisuje się też $\mathrm{w}$ wielowiekową tradycję piśmiennictwa przyrodniczego, którego początki sięgają starożytności.

Polski przekład poprzedziły liczne europejskie tłumaczenia dzieła (np. niemieckie z $1531 \mathrm{roku})^{2}$, które być może również odcisnęły swój ślad na ostatecznym kształcie naszej edycji ${ }^{3}$. Przenikanie do Polski w wieku XV humanizmu łączyło się z zainteresowaniem obcojęzyczną literaturą. Ożywiają się w tym czasie kontakty z Włochami, które rozwijają się w początku kolejnego stulecia, za panowania Zygmunta Starego i jego drugiej żony - włoskiej księżniczki Bony Sforzy. Nowe prądy, wśród których znalazło się też dążenie do poznania prawd rządzących przyrodą, stały się impulsem do poznania i tłumaczenia na rodzimy język różnych tekstów przekazujących wiedzę o otaczającym nas świecie, $w$ tym również tekstów użytkowych. Prężnie już w tym czasie działające drukarnie, głównie krakowskie, wydawały nie tylko pisma religijne, urzędowe, dydaktyczne, ale także gramatyki, zielniki, będące teoretycznym zapleczem i świadectwem rozwijających się dziedzin naukowych. Pierwszą edycję interesującego nas zabytku poprzedziło kilka wydań tekstów o tematyce ziołoleczniczej. To między innymi XV-wieczny poemat o ziołach autorstwa Macera Floridusa, w polskiej wersji opracowany przez Szymona z Łowicza (1532), pierwszy tekst botaniczny w języku polskim au-

2 Wspomniana tu wersja dostępna jest on-line: http://www.mgh-bibliothek.de/digilib/pdc. htm, Petrus < de Crescentiis>: Vom Ackerbaw, Erdtwucher und Bawleüten [Ruralia commodorum libri XII, dt.] [Straßburg] : Knoblouch, 1531. - [4], CLXXXII Bl.Bibliogr. Nachweis: VD 16 P 1836; [Die jüngere deutsche Übersetzung, erstmals gedruckt von Peter Drach, Speyer 1493, hier im vierten Nachdruck Straßburg 1531]

${ }^{3}$ W XV i XVI wieku ukazało się kilkanaście edycji poradnika. W Niemczech siedem wydań w języku łacińskim i dwa w niemieckim $(1493,1518)$, cztery w języku włoskim, w wieku XVI też dwie $(1529,1540)$ we Francji, w języku francuskim (Ochmański 1965: 22). 
torstwa Stefana Falimirza „O ziołach i o mocy jich...” (1534) (por. Jankowiak 2005: 7-23; Klemensiewicz 1985: 322-323; Kosiek 1983: 417-418; Spólnik 1990: 8-9).

\subsection{Polskojęzyczne wersje tekstu}

Do roku 1549, kiedy to w oficynie Heleny Unglerowej (Florianowej) wyszło pierwsze polskie tłumaczenie poradnika Krescencjusza, zatytułowane „Piotra

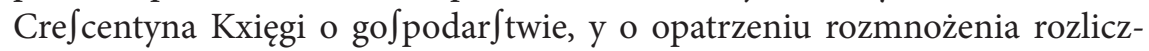
nych pożytkow, każdemu $\int$ tanowi potrzebne" ${ }^{5}$, nie ukazała się w Polsce żadna książka rolnicza. Nie było też przekładów dzieł starożytnych autorów, Palladiusa, Columelli, Varona. XVI-wieczny przekład średniowiecznego poradnika gospodarczego był więc pierwszą publikacją rolniczą, jedynym pełnym kompendium wiedzy z zakresu prowadzenia gospodarstwa ${ }^{6}$. Druga edycja tekstu - będąca podstawą materiałową - ukazała się po ponad dwudziestu latach od pierwszego wydania, w roku 1571 i nosi - nieco zmieniony w sto-

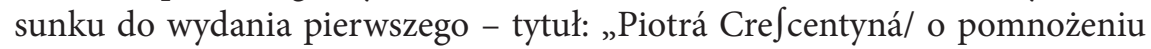

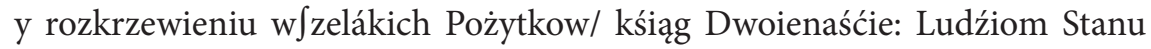

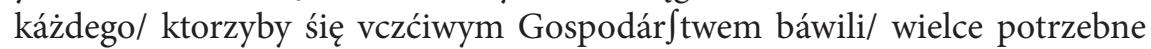
á pożyteczne"7. Dzieło wydrukowano również w Krakowie, ale w oficynie Sta-

${ }^{4}$ Dzieło to $\mathrm{w}$ XVI wieku trzykrotnie wznawiano. Pierwszy raz przez Hieronima Spiczyńskiego „O ziołach tutecznych i zamorskich i o mocy ich” (1542), po raz drugi wydrukowane po śmierci Autora w 1556 roku, kolejna edycja pt. „Herbarz, to jest ziół tutecznych, postronnych i zamorskich opisanie..." opracowany przez Marcina Siennika pochodzi z 1568 roku. Szczegółowe badania zależności późniejszych tekstów od Falimirza przeprowadził Jan Szostak (1976: 389-404; 1978: 5-37; 1979: 5-48; por. Jankowiak 2005: 11-12, 17-18).

${ }^{5}$ Korzystam ze zdigitalizowanego wydania zabytku (CD Sd.2 - Stare druki BUW, Zielniki XVI-XVIII w. cZ. I).

${ }^{6}$ Po pierwszej edycji dzieła ukazały się inne polskie prace o podobnej tematyce, poświęcone jednak na ogół szczegółowym zagadnieniom. Wśród nich warto wymienić książkę Erazma Glicznera pt. „Nauka i praktyka, z której rozmaite czasy i czasów postępki a przygody wyrozumieć” (1558), szkic Adama Micińskiego „O świerzopach i ograch tj. o przyswajaniu dzikich koni” (1570) i popularny, wiele razy wznawiany tekst o rybołówstwie pt. „O sprawie, sypaniu, wymierzaniu i rybieniu stawów, także o przekopach, o ważeniu i prowadzeniu wody" Olbrychta Strumieńskiego (1573), a także „Myślistwo ptasze” (1584) Mateusza Cygańskiego. Ta ostatnia pozycja, cenne historyczne źródło, w literaturze przedmiotu jest nazywana „perłą literatury ornitologicznej" (Kowalska 1883: 337). Zawarto w niej bowiem informacje na temat sposobów łowienia ptactwa, opisy - dziś już nieistniejących rodzajów - sieci, charakterystykę ponad stu gatunków ptaków, ich biologii, siedlisk i obyczajów (por. Kowalska 1983: 337).

7 Zabytek ten był już bazą materiałową i przedmiotem rozważań w kilku pracach Autorki (Kamper-Warejko 2009a, 2009b; 2009c; 2013; 2014). 
nisława Szarfenbergera. Dopiero kilkanaście lat po tej publikacji, pod koniec stulecia, pojawia się obejmujący całokształt dziedzin rolniczych, ale o charakterze ekonomicznym, tekst Andrzeja Gostomskiego pt. „Gospodarstwo” (1588), popularny i trzykrotnie wznawiany w wieku XVII.

Stanowiący podstawę artykułu tekst poradnika mieści się na 190 kartach $^{8}$. Źródłem pomocniczym jest jedna z XV-wiecznych łacińskich wersji zabytku („Ruralia commoda”, Löwen, zwischen 1477 und 1483) ${ }^{9}$. Porównanie obu tekstów uwidacznia pewne różnice w układzie poszczególnych części oraz zawartości treściowej ${ }^{10}$. Nie znamy autora polskiego przekładu, choć na marginesie różnych prac badawczych pojawiały się hipotezy przypisujące autorstwo Andrzejowi Trzecieskiemu i Andrzejowi Glaberowi (Hrabec, Pepłowski 1963: 48; Karplukówna 1971: 39; Kawecka-Gryczowa 1983: 314; Linde 1854: 48; Maciejowski 1851: 642 ${ }^{11}$; Migdał 1999: 21; Pankowicz 1979: 57-60; por. Osiewicz 2013: 42), a redakcję drugiego wydania - Marcinowi Siennikowi (Pankowicz 1979: 51). Niestety nie jest też znany bezpośredni pierwowzór polskiego druku ${ }^{12}$. Próba znalezienia odpowiedzi na pojawiające się pytania i ustalenie tych faktów wymagają dokładnych studiów filologicznych i porównawczych. Tu problem ten tylko się sygnalizuje. Lektura i badanie tekstu pozwalają na stwierdzenie, że autorem polskiej wersji była osoba obeznana $\mathrm{z}$ tematyką przyrodniczą, dobrze orientująca się w podjętej problematyce. Świadczą o tym między innymi liczne podobieństwa do polskich, XVI-wiecznych zielników (Falimirz, Siennik; Kamper-Warejko 2009b) i ko-

${ }^{8} \mathrm{Na}$ kartę składają się dwie strony. Sygnatura biblioteczna zabytku: Cim 8145 BJ; Wykorzystuję tekst - udostępniony przez Pracownię Słownika Polszczyzny XVI wieku: sygn. F193, inw.202.

9 Wersja dostępna on-line - http://digi.ub.uni-heidelberg.de/diglit/crescentiis1477/.

${ }^{10} \mathrm{~W}$ obrębie prezentowanych w poszczególnych księgach zabytku opisów roślin, anonimowy tłumacz naszego tekstu odszedł od układu alfabetycznego (taki też w jednej z niemieckojęzycznych wersji poradnika - Strasburg 1531) i zredukował ilość opisów (możemy to stwierdzić na przykładzie polskiej ks. VI „...o płodnych Drzewach/ y o przyrodzeniu ich”, w której zamieszczono czterdzieści cztery opisy pięćdziesięciu dwóch gatunków drzew i krzewów, zdecydowanie mniej niż w odpowiadającej jej w wersji łacińskiej i niemieckiej ks. V, w łacińskiej - 62, w niemieckiej - 61 roślin; wszystkie teksty łączy tylko podział prezentowanych w tej księdze roślin na drzewa płodne - dające owoce i niepłodne, te które owoców nie rodzą).

${ }^{11}$ Maciejowski - uznając Trzecieskiego za tłumacza dzieła - powtórzył przypuszczenie Chromińskiego (Chromiński 1806: 140). Ta dziewiętnastowieczna hipoteza badacza nie rozstrzygała czy chodzi o ojca, czy o syna. Do połowy XX wieku pogląd ten przewijał się w literaturze przedmiotu (Moszczeński, w pismach o A. Gostomskim - Bergerówna, Inglot, Lipiński).

${ }^{12} \mathrm{~W}$ ubogiej literaturze przedmiotu mówi się o podobieństwach z niemieckojęzyczną wersją łacińskiego tekstu. W XIX wieku zwrócił już na to uwagę Józef Rostafiński, później też inni badacze (Rostafiński 1888: 24; Ochmański 1965: 22; Pankowicz 1979: 55). 
rzystanie - w obrębie słownictwa botanicznego - ze średniowiecznej tradycji nazewniczej ${ }^{13}$. Oprócz treściowych związków z herbarzami (ks. III, ks. IV, ks. VI; również w opisach zwierząt - ks. VIII i ks. IX) poradnik łączy z nimi również osadzenie w starożytnej tradycji piśmienniczej. Podobnie jak w zielnikach, tak i tu często przywołuje się poglądy dawnych uczonych i powołuje się na ich nauki ${ }^{14}$.

Najczęściej pojawiają się odwołania do Palladiusa (jego nazwisko użyto w tekście aż 73x) i dlatego zapewne uznaje się, że autor poradnika oparł swoje nauki głównie na radach twórcy „Capita rei rusticae libri XIV” (Brzozowski 1983: 484). Cytowani są też jednak i inni starożytni autorzy dzieł przyrodniczych oraz rolniczych, tacy jak np. Warro (50x), Awicenna (38x) i Albert Wielki $(20 \mathrm{x})^{15}$. Odwołania do ich pism znajdujemy w różnych częściach tekstu, najczęściej wprowadza się je czasownikiem w 3. os. lp. „pisze...” Od księgi III - głównie przy okazji opisu zbóż, warzyw i ziół - wymienia się Pliniusza Starszego (17x), Izaaka (nazywanego tu „filozofem”; 17x), Dioskoridesa (16x), Izydorusa $(10 x)^{16}$, Columelli (9x), lekarza Gallenusa (9x), Katona (8x) i Arystotelesa (7x). Trzech dawnych uczonych - Wergilius (9x), Marcialus Gargilius (7x) i Burgundius (4x) - cytowanych jest wyłącznie w niektórych księgach. Ich specjalistyczna wiedza została wykorzystana między innymi w ks. $\mathrm{X}$ opisującej hodowlę pszczół (tu Wergilius i zapewne nawiązania do czwartej księgi jego „Georgik”), we fragmentach dotyczących uprawy i pielęgnacji drzew i krzewów (Marcialus Gargilius, np. 229, 399, 403, 425, 507) i w ks. V „O Winie”, traktującej o uprawie i pielęgnacji winorośli oraz sporządzaniu,

${ }^{13}$ W warstwie leksykalnej widocznym śladem tej świadomości i merytorycznego przygotowania jest umiejętność dokonywania wyboru spośród wielu wariantów takich elementów języka, które były już w polszczyźnie znane i używane w określonej funkcji. Przykładem może być podstawianie w miejsce łacińskich domesticus i silvestris polskich określeń, szczególnie interesujące w przypadku, kiedy być może uwidacznia się świadomy wybór autora bądź redaktora, np. na ogół szałwija domowa, ale dla sadźca konopiastego obok szałwiji leśnej - dokładne tłumaczenie łac. silvestris - częściej pojawia się wyrażenie szałwija polna, która funkcjonowała już w polszczyźnie dla tej rośliny.

14 W całym tekście znajdujemy odwołania do trzydziestu czterech starożytnych i średniowiecznych autorytetów w dziedzinie nauk przyrodniczych, też do mniej znanych praktyków i teoretyków.

15 W polskim tłumaczeniu powtarza się je za łacińską wersją tekstu. Cytowania te jednak nie były przedmiotem szczegółowych analiz Autorki.

16 Ponieważ imię to nosiło dwóch świętych - żyjący na przełomie VI/VII w. biskup Sewilli - autor książki o cudach natury i tekstu pretendującego do rangi pierwszej naukowej encyklopedii oraz św. Izydor Oracz - patron rolników - żyjący na przełomie X/XI wieku, nie rozstrzyga się tu, na którego Izydora powołuje się autor poradnika. Nie jest to tematem tego szkicu (por. NEP 3 1995: 112). 
przechowywaniu i różnych gatunkach wina (Burgundius). Już na tej płaszczyźnie tekst staje się swoistym pomostem łączącym historię z XVI-wieczną rzeczywistością, przekazuje dawną wiedzę i doświadczenia pokoleń jak się okazuje nauki i poglądy uniwersalne, przydatne i wykorzystywane w różnym czasie i różnych częściach świata.

Ze starożytnych dzieł, ale prawdopodobnie też z praktyki i własnych obserwacji, przytacza się w zabytku różne opinie i sądy, zarówno ogólne, na przykład na temat gospodarowania, jak i szczegółowe, dotyczące konkretnych roślin, zwierząt, jakichś kwestii związanych $\mathrm{z}$ ich uprawą lub hodowlą. Są wśród nich rady „doświadczonych gospodarzy”, zakonników, ogrodników, lekarzy, Greków. Wprowadza się je najczęściej czasownikiem uwypuklającym oralny przekaz tradycji, poglądów i doświadczeń, nierzadko wykorzystując zaimek pierwszoosobowy wskazuje się na bezpośredni kontakt i własne doświadczenie, np. „powiádał mi...; powiádáią...; powiádáią też ludźie...” (112, 119, 173, 312, 314, 353, 359, 362, 440, 463, 504, 508, 593); „Grecy náuczaią...” (331), „Grekowie ták czynić navczáli...” (504), „Powiádáią też Grecy...” (508) i in. Dla wzmocnienia oddziaływania podanych opinii zdarza się użycie form

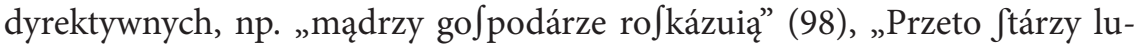

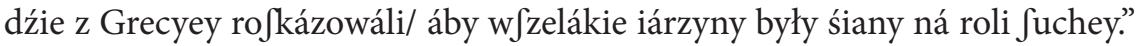
(112). Niejednokrotnie w polskim tekście pojawiają się odwołania do obcych - głównie włoskich - zwyczajów (105, 151, 160, 162, 176, 186, 188, 194, 214, 219, 260, 262, 294, 316, 393 i in.). To właśnie w takich miejscach pisarz lub tłumacz czuje się zobligowany do wyjaśniania i przybliżania czytelnikowi obcych realiów oraz tłumaczenia nieznanych nazw i pojęć.

\section{Analiza wybranych fragmentów przekładu poradnika Piotra Krescencjusza dokumentujących przenikanie kultur}

W tak wielowarstwowym genetycznie tekście nieuniknione staje się przenikanie duchowego i materialnego dorobku różnych społeczności żyjących na przestrzeni wieków, w tym wypadku najczęściej dorobku agrarnego i szerzej - przyrodniczego. Przedmiotem niniejszego szkicu są zamieszczone w polskim wydaniu poradnika, wyraźnie wyodrębnione graficznie, bo podane $\mathrm{w}$ nawiasach ${ }^{17}$, wyjaśniające uwagi autora i prześledzenie, jak

17 Znaki takie stosowano w różnych tekstach epoki, mieszczą się one w zestawie używanych w tym czasie znaków interpunkcyjnych. Nawias - podobnie jak dziś - spełnia funkcję wydzielającą. Problem funkcji znaków interpunkcyjnej i delimitacyjnych poruszyła ostatnio w swoim szkicu, 
za ich pomocą starano się adaptować obce realia i zapoznawać z nimi odbiorcę. Poczyniono próbę wyszczególnienia ich rodzajów i funkcji. Dopiero bliższe przyjrzenie się tym fragmentom tekstu i porównanie ich z dostępną $\mathrm{XV}$-wieczną łacińską edycją poradnika pozwala na stwierdzenie, że graficzne wyróżnienie nie zawsze jest oryginalnym odautorskim komentarzem. Część z wyekscerpowanych przykładów znajduje odbicie w tekście łacińskim, tam zawsze jednak bez nawiasów. Analizowany materiał trzeba więc traktować jako - wybrane na potrzeby niniejszego tekstu - fragmenty zabytku, cechujące się tym, że podano je w nawiasach (z całego tekstu wynotowano 167 takich zapisów). Są one swoistą ilustracją i reprezentacją obecnych w całym dziele językowych wykładników przenikania kultur, podobne bowiem, a często tė̇ identyczne, frazy i konteksty pojawiają się bez graficznych wyróżników. Nawiasy, w których umieszczono cytowane poniżej przykłady, można by więc zastąpić innymi znakami o podobnej funkcji, np. przecinkami. Wszystkie te zapisy pełnią funkcję objaśniającą, informacyjną, dopełniającą, trudno więc zarysować w ich obrębie klarowne i bezdyskusyjne granice. Przedstawiony tu podział wyekscerpowanych cytatów ma wyłącznie charakter porządkujący i umowny.

Pierwsza - wyraźnie wyodrębniająca się - grupa przykładów to wspomniane już wcześniej, podane w nawiasach, ale i bez nich, wskazówki, dotyczące cytowanych źródeł. Niezależnie od obecności bądź braku graficznego wyróżnika odwołania do autorytetów zawsze znajdują odzwierciedlenie również w łacińskiej wersji poradnika. Oto kilka wybranych na potrzeby tego tekstu, a więc zamieszczonych w nawiasach, przykładów takich odwołań:

„(...) (iáko Avicenna pifze) (...) (według náuki Miftrzá Pálladiufá).” (5); „Gdyż

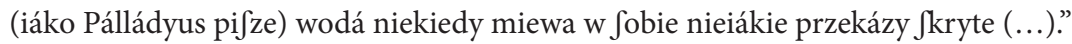
(13) lub „(iáko on czyfty gofpodarz Pálládyus vczy)” (32); tak też w innych miejscach (30, 105, 138: (...náucza), 150, 484-5, 575); „(iáko pifze Wielki Woyćiech).”

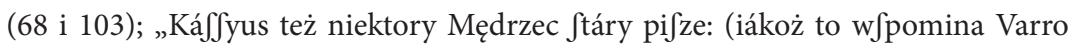

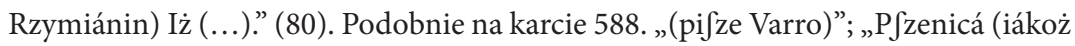
to wypifuie Ifáák filozof) ieft (...).” (157); „Z tego drzewá (iáko powiáda Ifidorus) w Ziemi: Włofkiey nád rzeką Eridanem/ y w Syryey gdźie Zydowie pierwey byli/ wyćieka żywicá ktora ieft bárzo lekárfka (...).” [o topoli białej] (456). Mówiąc o różnych sposobach kształtowania owoców, wspomina się, że „Drudzy záśię (pifze Albertus) (...)." (510), a odwołując się do wcześniejszych fragmentów tekstu, podaje

opisującym grafię XVII-wiecznego tekstu (1617), między innymi Anetta Luto-Kamińska (LutoKamińska 2015: 27). 
„(iáko tenże Varro piðze iteż Palladius) (...).” (513). Jak już wcześniej wspomniano, przywołanie nauk i wiedzy mistrzów i poprzednich pokoleń - mądrych i doświadczonych - wzbogaca wiedzę czytelnika, kształci go, np. „Słuðza to wiedźieć/ iż cię ¿kość álbo lekkość wody (według doświádczenia mądrych ludźi) wiele czyni ku poznániu wody.” (9) i dalej „Może też (iáko doświadczeni powiadáią) (...).” (598). Niekiedy dzięki wykorzystaniu znaczeniotwórczej (składniowej) roli szyku zdaniowego, cytat taki wzmacnia przedstawiany sąd: „Sofná też drzewo znáiome które (iáko powiádáią mądrzy) dawa pożytek w〕zytkim rzeczom (...).” (463).

Z kolei różnego rodzaju wtrącenia, których nadrzędną funkcją jest funkcja informacyjna, najczęściej rozwijają wcześniej podaną treść, nawiązują do niej i dopowiadają. Takie cytaty stanowią niemalże połowę wynotowanych zapisów $^{18}$. Interesujący nas tu kontekst kulturowy dobrze oddają następujące wybrane przykłady:

„(...) przeto gdźie ieft gorąco wielkie/ á máło wilgośći (iáko ieft w Murzyńfkiey źiemi) tám ludźie nie mogą być trwáli (...).” (14)

„Tákież śię przygadza w pomoráńczowym owocu. (Jáko y v nas z dobrego náśienia

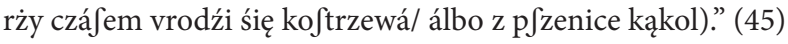

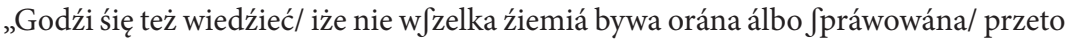
ludźie w Egipćie (gdźie naprzod oranie iteż śianie wymyślono/ y gránice rolne wymierzono) źiemię płodną álbo rolą czworáko rozdźieláli.” (90)

„Tákową rolą Egipfcy ludźie (ktorzy na pierwey oránie wynaleźli) nie zwáli nowiną (...)." (102)

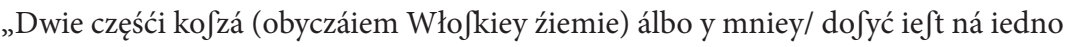
Stáiánie." (167)

„Ma być pożęt bob/ álbo wyrywan Kśiężycá Czerwcá (á to w ćiepłych Jtronach) iuż

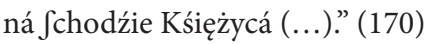

„(...) á gdy iuż będźie wymłocona/ choćia bydłem (obyczayem Włofkim) albo cepami (...)” (186)

${ }^{18}$ Wśród nich są i takie, które treściowo odpowiadają podobnym fragmentom w łacińskiej wersji tekstu, np. „Jeft nátura wilgotna á źimna/ (chybá z nieiákiey zewnętrzney przyczyny iey przećiwney.) (...) ks.I, $8 ;$ „(...) que frigida et bumida $\int i$ nulla caufa extrin $\int e c a$ fuerit con traria (...)" ks.I. Przykładowe lokalizacje fragmentów o podobnej funkcji to, np. 10, 22, 25, 32, 37, 39, $44,47-50,53,59,61,64,91,99,108,120,129,200,298,324,358$ i wiele innych. 


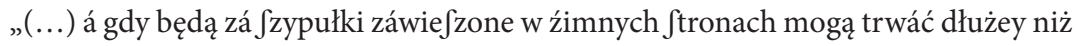
do roku/ zwła zczá (iáko powiádáią) gdy rwąc ie rękomá śię ich nie dotyka gołemi (...)." (412)

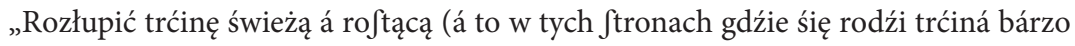
miążjza iáko lafki) tám (...) nákłáść rożanych pączkow (...)” (499)

Jak widać, wstawiane $\mathrm{w}$ nawias fragmenty tekstu są różnorodne - od wyrażeń i krótkich fraz, po całe, czasem rozbudowane, zdania. Mogą one informować o obcych obyczajach i realiach, zestawiać i porównywać te realia z rodzimą rzeczywistością, przybliżać historię i wzbogacać wiedzę czytelnika o świecie.

Trzecią licznie reprezentowaną grupą cytatów są takie, które dotyczą bezpośrednio leksyki. W nawiasach wyjaśnia się znaczenia słów, tłumaczy je lub nazywa się wcześniej opisane zjawisko, rzecz, pojęcie, czasem sygnalizuje się pochodzenie słowa, nierzadko podaje się też synonimy, obce lub rodzime odpowiedniki przytoczonej nazwy.

„(...) miáfto tego może zyndry (to ieft cegły w piecu Jpiekłej) nákłáść.” (33)

„Czynią też z niey plaftr ná pedogrę (to ieft nożną dnę) (...).” (164)

„Weźmi Squille (ieft to cebulá zamorfka w Aptece) (...).” (363) ${ }^{19}$

„Z iábłek może być pićie (ktore iábłecznikiem zową) (...).” (383)

„(...) tedy náfypáć Jtártego Re álgaru (ieft to fárbá żołta á bárzo iádowita/ w áptece ábo v málárzow) zową ią po niemiecku Raifgal (...).” (527)

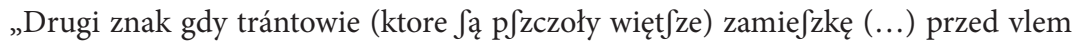
látáiąc czynią (...)." (606)

„(...)káżdy nad dźieśięć tyśięcy lextariow/ (była to miárá rzeczy lipkich á wilkich v Rzymianow coby v nas dwá funty miodu albo oliwy záważyło/ iáko pifze Ifidorus/ Plinius y Africanus/ choćia inaczey rozumie Alciatus etc.) (...)." (610)

${ }^{19}$ W tekście łacińskim znajdujemy tylko podaną tu łacińską nazwę: „Accipe đquillaz (...)”. 
Wydaje się, że wśród tych przykładów jest największy odsetek uwag autorskich lub redaktorskich, szczególnie przy wskazaniu rodzimych określeń odpowiadających opisanym treściom. Wprowadza się je na ogół w zdaniach z orzeczeniem „zową” w 3. os. l.mn., z okolicznikiem miejsca, którego składową są różne pluralne zaimkowe formy pierwszoosobowe, np.

„Lekárze też rádzą pożywáć krup owieśnych wárzonych (które v nas grucą zową) (...)." (166)

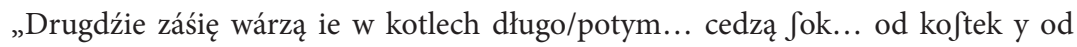

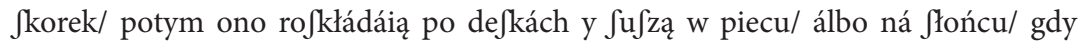

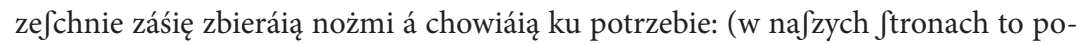
widłámi zową.)." (391)

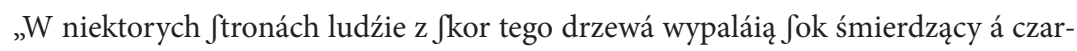
ny/ lipki też iáko Jmołá na wiele rzeczy potrzebny (v nas to dźiegćiem zową.)." (472)

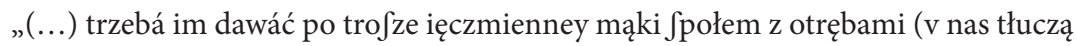
zową) (...)." (517) ${ }^{20}$

Czasem w nawiasach pojawiają się całe zdania, w których podmiot zbiorowy wyrażony jest 1. os. l.mn. - tak na przykład we fragmentach dotyczących hodowli gołębi i łowienia królików:

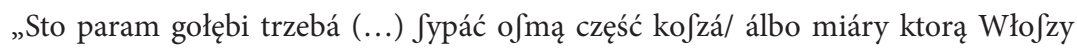
zową corbis (my możem rzec o o mą część wiertelá) (...) (586) [wiertel 'ćwierć (miara objętości)' PSDP 553]

„Potym iedną dźiurą wpuśći w iámę ich furektá (ieft to źwierzę więt $\int z e$ niźli łáśica/ wła nny krolikom nieprzyiáćiel podobny/ my pilchem leśnym albo polnym zowiemy) którego ma mieć domá chowánego (...).” (641)

Niekiedy rodzimy synonim wprowadza się wprost wyrażeniem „po polsku...":

${ }^{20}$ Inne przykłady nie wprowadzają już językowego elementu subiektywizmu, sygnalizującego przynależność piszącego do jakiejś grupy - etnicznej, narodowej, kulturowej. Informuje się tylko czytelnika jak nazywa się dane zjawisko lub rzecz, np. „SOK ieft wilkość dźiurkámi korzeniowymi (ktore pory zowią) wćiągniona wnątrz/ á ćiepłem (...) Jprawiona ku dawániu im żywnośći." (663) 


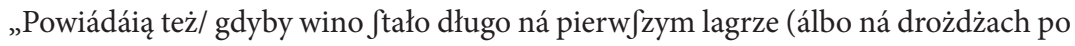
Pol $\left.\int k u\right)$ tedy gdy ćiepło przydźie ták śię wino z nim złączy á Jmaku iego nábędźie (...)” (344); „(...) nádeń w ftáwić naczynie drzewiáne choćia gliniáne z Jzerokim dnem (po polfku to lijem zową) áby (...)." (33)

Innym razem, podając nazwę obcą, wzbogaca się wiedzę czytelnika i informuje o jej pochodzeniu, np.:

„Drugi ieft rodzay málonow podługowáty a trochę Jkrzywiony (zową ie Włofzy Melangule) te iedzą zá młodu poki fą źielone (...).” (230), w łacińskim tekście w tym miejscu czytamy „(...)et vocat melanguli (...)”. Jak widać, w tekście polskim odniesiono się do włoskiego pochodzenia nazwy.

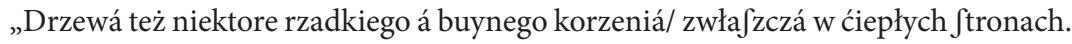
Jákie $\int a ̨$ ku południu we wtorey trzećiey y $\int$ nać czwartey kráinie świátá (co Láćinnicy Elima zową) gdźie nie częfto de $z c z$ Jpada (...)." (51), podobnego uzupełnienia nie znajdujemy w łacińskim tekście.

W analizowanym materiale zasygnalizowano również bogactwo i różnorodność leksyki, które są nie tylko świadectwem sprawności językowej tłumacza, ale także ilustracją rozwoju systemu języka, jego odmian stylistycznych oraz rozwijającej się kultury materialnej. Podawanie synonimów ukazuje zróżnicowanie słownictwa (np. „drudzy..” 33, 302, 360, 378, 571 ${ }^{21}$; „iedni... drudzy...zową” 67322; „...iáko niegdźie zową” 688 23 ), w tym też zróżnicowanie środowiskowe (np. „á te zowią Lekárze...” 55 24 , „iáko mowią Gwiazdozor-

${ }^{21}$ „W niektorych kráinach (...) máią nieiáką kretę álbo wapno z ktorego tło (álbo iáko drudzy zową tłoki) ták czyśćie vbiją y vdepcą (...).” (33); „Ale gdźie ie tt nie zarofła nowiná/ tám zagony tylko wzrywáć ábo grudy (drugdźie grzędámi zową) (...)” (302); „(...) iż náśienie Porowe albo (iáko drudzy zową) Lukowe (...) ma być wpufzczáne. (360); „Szkodzą też drzewu bárzo wą-

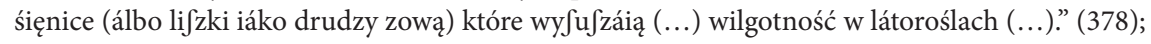
„(...) záiące iteż kunki (drudzy ie czarnymi krolikámi zową) chowány bywáią.” (571)

22 „Trzebá pilno báczyć áby śię odmłodźi (które iedni wilki drudzy bękártami zową) ze pnia

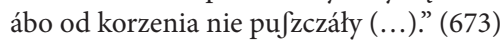

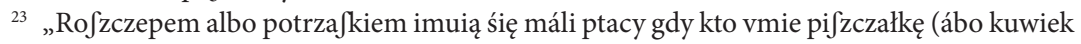
iáko niegdźie zową) (...)” (688)

${ }^{24}{ },(. .$.$) w wzy ftko śię sftawa z żyłek rozpiętych y rozejzłych po ćiele: (á te zowią Lekárze/$ częśći wrodzone iteż nie Jkłádne) (...)” (55) 
cy” $106^{25}$, „iáko zową winarze” $315^{26}$, „...iáko bártnicy zową” 695-6², z zakresu rybołówstwa „zową ią...” 644 ${ }^{28}$ ) i regionalne (np. „...álbo iáko gornicy zową..." 27, 2929). Tylko w nawiasach takich zapisów zarejestrowano ponad dwadzieścia, np. „(...) bowiem niektorzy miewáią konew ołowną álbo cenową (ktore zową allembik) (...).” (498) [allembik 'bania, kociołek, kolba’ PSDP 6]. W wyróżnionych graficznie informacjach o pochodzeniu słów są też takie, które wskazują na potoczny charakter i powszechne użycie wspomnianych

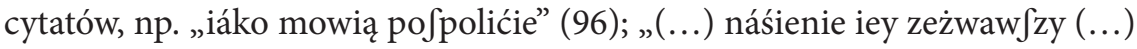

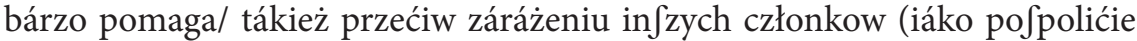
mowią) od powietrza (...)” (242, o gorczycy); „(...) źiele też to w winie warzone/ ná członek powietrzym (iáko mowią) zabity przykładáne barzo pomaga.” (255)

Podobną funkcję informacyjno-wyjaśniającą pełnią też przykłady, które uszczegóławiają wcześniej podaną treść słowa lub wyrażenia. Ponieważ z jednej strony tłumaczą i wyjaśniają wcześniej przytoczony kontekst, wyrażenie, wyraz, a z drugiej wyraźnie ograniczają jego zakres znaczeniowy i precyzują treść, można zaliczyć je do grupy wtrąceń dotyczących słownictwa. Czasami przykładom tym odpowiadają podobne lub niemal identyczne cytaty w tekście łacińskim. Oto ich wybór:

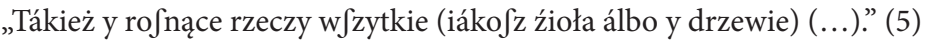

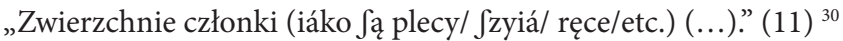

${ }^{25}$ Wyjaśnia i komentuje się tu termin używany przez osoby zajmujące się badaniem ciał niebieskich - astronomów lub przepowiadających przyszłość z gwiazd - astrologów, np. „Tegoż też czáfu gdy kśiężyc będźie w Kozorożcu (iáko mowią Gwiazdozorcy) (...)." (106)

${ }^{26}$ „Przy goleni máćice (iáko zową winarze) cożkolwiek wyrośćie/ ma być obrzynano (...)” (315)

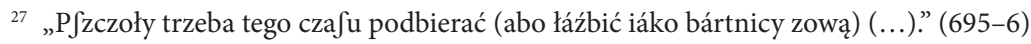

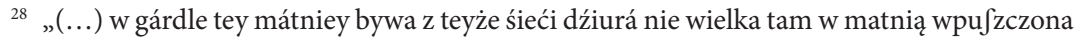
y rozpięta (zową ią Jerce) práwie w pośrzodku áby tędy rybá ... wleść(!) nie mogłá (...).” (644) Inny

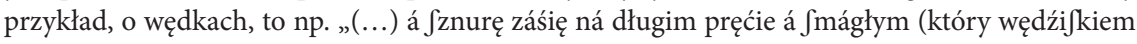
zową) zawieśić." (646)

${ }^{29}$ Przytoczone tu przykłady poświadczają regionalną wariantywność słownictwa, tu od-

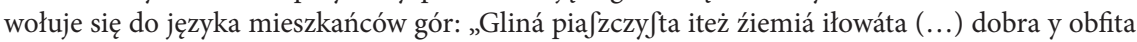

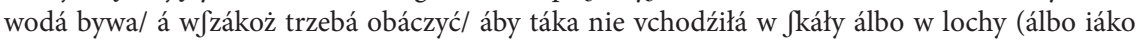
gornicy zową) w kluchty nieiákie.” (27); „Ale ktoby chćiał z gory wywieść wodę/ muśi z wierzchu gory áż do wody gżynek/ álbo hyntloch (iáko gornicy zowią) przebić (...).” (29)

${ }^{30}$ W tekście łacińskim czytamy: „(..) et bumeri et colla (...).” 


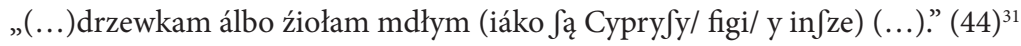

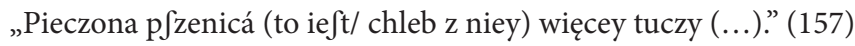

„(...)áby tám czá $u$ Jwego (iáko kśiężycá Lutego/ Márcá/ tákież ná Jeśień Páźdźierniká/ Liftopádá) wierzbą albo topolą/ więzem álbo (...) ofádźił (...).” (21) ${ }^{32}$

„(...)gnoiu bydlęcego (iáko koźiego álbo owczego etc.) (...).” (81) ${ }^{33}$

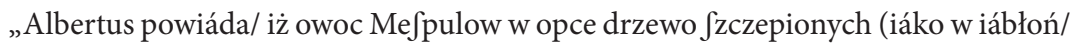

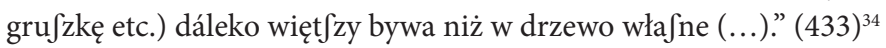

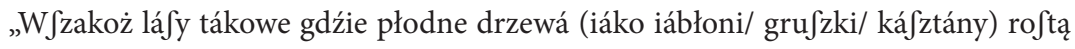
$(\ldots) . "(486)^{35}$

„Náwarz łupinu źielá (który zową wilczy ábo Jłoneczny groch) (...).” (559)

„(...)naczynie (coby iedno wy fokie a nie bárzo fzerokie) (...).” (600)

Czasem jednak wyjaśniające i precyzujące wtrącenia autora bądź redaktora polskiego przekładu są uzupełnieniem tekstu, nie znajdujemy podobnych w wersji łacińskiej, co świadczy o swobodnym podejściu do pierwowzoru, dbałości o precyzję przekazywanych treści oraz jak najlepsze zrozumienie tekstu przez odbiorcę. Oto przykłady:

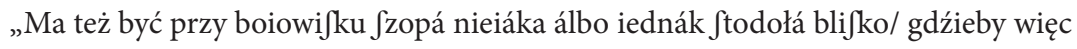

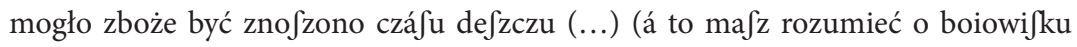
ktore nie pod przykryćim bywa/ ále profto między gumnem. Jáko tego ieft obyczay w źiemi Włojkiey.)” (151)

${ }^{31}$ Po łacinie w tym kontekście: „(...) cipre $\iint i$ vel ficus (...).”

${ }^{32}$ Po łacinie czytamy: „(...) circum circa tempore congmo videlicer octobris uel nouembris februarii uel martii."

${ }^{33} \mathrm{~W}$ tekście łacińskim, nie dokładnie tak, jak w polskim, ale podobnie: „(...) Jtercoris Sparge vel caprinum manu (...)."

${ }_{34}$ Odnośny fragment znajdujemy w łacińskiej wersji poradnika w ks. V, traktującej jak polska ks.VI - o drzewach: „Albertus autem dicit $\int \mathrm{i}$ quando in $\int i \mathrm{do}$ fit de eis $\int u p e r$ truncum alterius generis $\int c i l i c e t$ mali vel piri vel etiam aliculus $\int$ pine tune fructus eius multum (...).”

${ }^{35}$ Niemalże takie sam fragment znajdujemy po łacinie (ks.VII): „Nec autem nemora pcuranda Junt diuerfimode. uam ca in quibus $\int u n t$ caftanee piri et mali et $\int i m i l e s$ arbores fructum ferentes (...)." 
„(...)Aryftoteles wielki Mędrzec mowił/ iż kśiężyc czyni to [obracanie] przez ieden mieśiąc (to ieft przez trzydzieśći dni) co đłońce dźiáła przez cały rok (...)” (108)

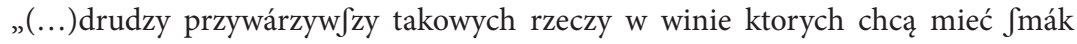

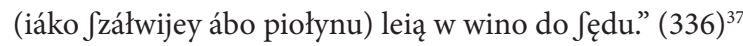

\section{Uwagi końcowe}

Zasygnalizowane w temacie przenikanie kultur można tu zaobserwować zapewne na różnych płaszczyznach. Jak każdy tekst adaptowany do innych realiów, przekazujący nauki i poglądy wielu autorów jest nośnikiem informacji o świecie i źródłem do poznania obcych zwyczajów, języka i innych kultur. W przytoczonych tu przykładach wyraźnie uwidacznia się tożsamość autora polskiego przekładu, który wykorzystując różne formy pierwszoosobowe (zaimkowe, czasownikowe), konfrontuje obce kultury i obyczaje z rodzimą, której sam jest uczestnikiem i twórcą. Zaprezentowany tu materiał - jak w każdym tekście specjalistycznym - pełniący głównie funkcję informacyjną, zarazem objaśnia i tłumaczy tekst, czasem przybliża szerszy kontekst, jest też swego rodzaju językowym i tematycznym leksykonem, nierzadko zapoznającym czytelnika ze zwyczajami i kulturą innych narodów (jak np. we fragmencie zabytku mówiącym o zakupie folwarku - „(...) obacz iefli tám ieft dobry

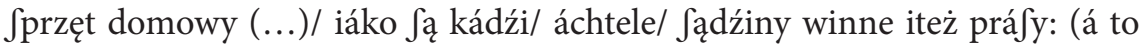

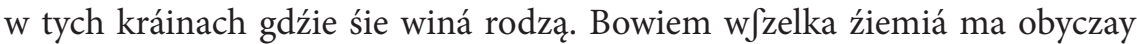
rodzáynośći Jwey.) (...).”39). Zauważalne, ale z powodu dość swobodnego tłumaczenia (być może też wykorzystania różnych pośrednich przekładów) trudne do wytropienia związki z tekstem łacińskim nie ograniczają inwencji autora polskiej translacji, który niejednokrotnie w komentarzach odautorskich stara się zasymilować obce realia, pojęcia i nazwy, dopowiedzieć szczegóły. Te wtrącenia i wyjaśnienia stają się swoistym pomostem między XIII-wiecznym tekstem pierwotnym, powstałym w kulturze śródziemnomorskiej a autorem polskiego tłumaczenia i czytelnikiem.

${ }^{36}$ Wstawionej w polskim wydaniu informacji nie znajdujemy w tekście łacińskim: „(...) ariftoteles dixit (...)luna facit in me $\int \mathrm{e}$ quod $\int \mathrm{ol}$ facit in anno boc eft byemem et eftate ver et autupnum quonia a prima (...)."

${ }^{37} \mathrm{~W}$ ks. IV łacińskiego tekstu, odpowiadającej w polskiej wersji ks. V, traktującej o winorośli i winie w odnośnym fragmencie czytamy: „Et generaliter Japorem et virtutem acquiret eius quod in eo loco ponetur/ $\int \mathrm{i}$ diebus congruis $\int \mathrm{i}$ mul ebulierint. $\int \mathrm{i}$ vue collecte quibus dem diebus in aceruo ftetariut/ vinum maturius erit." 


\section{Literatura}

\section{Źródła}

Piotr Crescentyn, 1571, „O pomnożeniu y rozkrzewieniu wfzelákich Pożytkow/ kśiąg Dwoienaśćie: Ludźiom Stanu káżdego/ ktorzyby śię vczćiwym Gospodár twem báwili/ wielce potrzebne á pożyteczne”, Kraków.

Petrus de Crescentiis, 1493/ przedruk 1531: Vom Ackerbaw, Erdtwucher und Bawleüten [Ruralia commodorum libri XII, dt.] [Straßburg] : Knoblouch, 1531. - [4], CLXXXII Bl.Bibliogr. Nachweis: VD 16 P 1836; [Die jüngere deutsche Übersetzung, erstmals gedruckt von Peter Drach, Speyer 1493, hier im vierten Nachdruck Straßburg 1531]; http://www. mgh-bibliothek.de/digilib/pdc.htm (dostęp: 16 czerwca 2016 r.).

Crescentiis Petrus de Ruralia commoda, Löwen, zwischen 1477 und 1483: http://digi.ub.uni-heidelberg.de/diglit/crescentiis1477/ (dostęp: 16 czerwca 2016 r.).

\section{Literatura przedmiotowa:}

Chromiński, K., 1806, O literaturze polskiej, „Dziennik Wileński”, t. III.

Hrabec, S., Pepłowski, F., 1963, Wiadomości o autorach i dziełach cytowanych w Słowniku Lindego, Warszawa.

Inglot, S., 1951, wstęp i objaśnienia w: Anzelm Gostomski Gospodarstwo, Wrocław, s. III-XXXIX.

Kamper-Warejko, J., 2009a, Kilka uwag o historii nazw ziół z poradnika P. Krescencjusza (1571 r.), „Studia Językoznawcze”, t. 8, Szczecin, s. 71-81.

Kamper-Warejko, J., 2009b, Nazwy roślin „z náśienia śię rodzących ná ogrodźiech ku żywnośći ludzkiey" u Krescencjusza a wybrane XVI-wieczne zielniki, „Białostockie Archiwum Językowe”, nr 9, Białystok, s. 115-126.

Kamper-Warejko, J., 2009c, XVI-wieczne nazwy polskich roślin jako świadectwo rozwoju języka. Na podstawie „Ksigg o gospodarstwie” Piotra Krescencjusza, [w:] Tajemnice rozwoju, D. Bieńkowska, A. Lenartowicz (red.), Łódź, s. 223-234.

Kamper-Warejko, J., 2013, Obce nazwy winorośli występujące w poradniku Piotra Krescencjusza (1571), „Studia Językoznawcze”, t. 12, Szczecin, s. $73-81$.

Kamper-Warejko, J., 2014, Historia polskich nazw roślin występujących $w$ poradniku P. Krescencjusza, Lin Cop 11, Toruń, s. 143-158.

Karplukówna, M., 1971, Regionalizmy w języku Andrzeja Cervusa z Tucholi, Wrocław. 
Kawecka-Gryczowa, A. (red.), 1983, Drukarze dawnej Polski od XV do XVIII wieku, t. 1: Małopolska, cz. 1: Wiek XV-XVI, Wrocław.

Klemensiewicz, Z., 1985, Historia języka polskiego, t. 2, Warszawa.

Luto-Kamińska, A., 2015, „Alfurkan tatarski” Piotra Czyżewskiego - opis zabytku (grafia z elementami fonetyki, „Studia z Filologii Polskiej i Słowiańskiej”, 50, Warszawa.

Maciejowski, W. A., 1851, Piśmiennictwo polskie od czasów najdawniejszych aż do r. 1830, t. 2, Warszawa.

Migdał, J., 1999, O języku Andrzeja Glabera $z$ Kobylina. Studium normalizacji polszczyzny wczesnorenesansowej, Poznań.

Ochmański, W., 1965, Wiedza rolnicza w Polsce od XVI do połowy XVIII, Wrocław.

Osiewicz, M., 2013, Wariantywność graficzna „Ksiagg o gospodarstwie” Piotra Krescentyna z 1549 roku. Studium przypadku, Poznań.

Pankowicz, A., 1979, Najstarszy polski druk z zakresu gospodarstwa wiejskiego (Piotr Krescentyn, Ksiegi o gospodarstwie... Kraków 1549 r.), „Zeszyty Naukowe Akademii Rolniczej w Krakowie”.

PSDP - Reczek, S., 1968, Podręczny słownik dawnej polszczyzny, Wrocław.

Rostafiński, J., 1888, Nasza literatura botaniczna XVI w. oraz jej autorowie lub tłomacze. Studium krytyczne, Kraków.

Wydra, W., Rzepka, W. R., 2004, Chrestomatia staropolska. Teksty do roku 1543, Wrocław, s. 375-378.

\section{Polish $16^{\text {th }}$ century translation of the guidebook by Peter crescentius as the evidence of cross-cultural diffusion}

\section{Summary}

This article focuses on explanatory comments provided by the author and highlighted in the text which appear in the second edition of the Polish translation of the guidebook by Peter Crescentius (1571). The aim of the analysis is their description, reference to the Latin original and the analysis of how these comments were used to adapt and make the reader acquainted with foreign reality. The author of the article attempted to classify their types and functions. The material is analysed with the use of linguistic and historical-comparative methods. The cross-cultural diffusion, emphasised in the title of the article, may be observed in a variety of aspects. The $16^{\text {th }}$ century translation, adapted to the Polish reality and transmitting the knowledge and opinions of many authors, constitutes a medium of information about the world as well as the source to become acquainted with foreign customs and names. What becomes visible in the analysed examples is the identity of the Polish author of the 
translation, who uses various forms in the first person (pronouns, verbs), compares foreign cultures and customs with the Polish culture and customs, the participant and creator of which he sees himself. The analysed material - as in any specialist text - plays mainly an informative role, explains the text, sometimes provides a wider context; it is also a kind of a linguistic and thematic lexicon that familiarises the reader with the customs and cultures of other nations. It may be noticed that the associations with the Latin original text are hard to observe, which results from a relatively free translation of the text and from using various translations of the text. Nevertheless, it does not restrict the translator's creativity to assimilate the foreign reality, terms and names and to provide detailed information. Comments and explanations tend to build a bridge between the $13^{\text {th }}$ century original text, created within the Mediterranean culture, and the author of the Polish translation and the reader.

Keywords: $16^{\text {th }}$ century translation of the guidebook by Crescentius, linguistic exponents of cross-cultural diffusion, specialist text, history of the Polish language 
